\title{
Editorial
}

\section{One year on, and a silver lining to the cloud}

Journal of Retail and Leisure Property (2006) 5, 253-254. doi:10.1057/palgrave.rlp.5100036

You will have noticed I'm sure that we now have a new cover, which I hope you will agree is very eye catching. I would like to thank DLG Architects for providing the image which we finally decided to use.

As promised earlier in the year, all new and archive articles from the Journal are now available to download in electronic format from the Journal website: www.palgrave-journals.com/rlp. Subscribers have free access to all current and archived content while non-subscribers will be able to purchase and download individual articles.

Also at the website, you will find details on the scope of the Journal, updated 'instructions for authors' and details of our 'E-alerts' table of contents alerting service as well as links to other related Palgrave journals which may be of interest.

This issue is the last of the current volume, which now means we have been publishing this Journal for a full year. The transition between publishers and subsequent transfer of production systems from external suppliers in-house has led to unexpected and frustrating delays and we are very appreciative of the patience of our subscribers and authors.

The retail and leisure industries constantly have to adapt to changes in consumer demand and behaviour as well as the cloud of external market forces such as increasing power/fuel costs and the impact of global terrorism. But it's not all bad. As the levels of personal borrowing increase and new consumer markets open up (in particular China and India), the level of global spending on retail and leisure activities is surely set to rise. The silver lining gets even shinier when one considers the ever-increasing expansion of the international budget airlines network. (International) air travel is for many as normal now as catching a bus; in fact, they probably fly more often, so more people are travelling further and with more to spend.

The Journal of Retail and Leisure Property aims to be a source of cutting edge and practical information and advice as we enter these exciting times for the Retail and Leisure industries which will have to adapt to attract new travellers and customers as well as try to keep regular/repeat customers satisfied. As new destinations open up, customers get more knowledgeable and profit margins get squeezed, new opportunities will arise, and the Journal will be there to guide you along the way. But this will only be possible if we continue to get practical, informative and high-quality articles from across the industry. I would therefore, encourage you to think about writing for the Journal or if you 
think there is something we should cover, either as a single article or a special/themed issue, I would welcome your suggestions.

Neil Henderson

Publishing Editor

September 2006

Tel: +44 (0) 1256302959 ext 3116

E-mail: n.henderson@palgrave.com 